\title{
Powdery-mildew-resistant PMR-1 Rutabaga Germplasm
}

\section{V.I. Shattuck \\ Department of Horticultural Science, University of Guelph, Guelph, Ont. $N 1 G 2 W 1$, Canada \\ B. Brolley \\ Agronomy Division, Centralia College, Huron Park, Ont. NOM 1YO, Canada}

Additional index words. Brassica napus, Erysiphe polygoni, vegetable breeding, disease resistance

Powdery mildew, a common disease of rutabaga [Brassica napus ssp. rapifera (Metzg.) Sinsk], is caused by the obligate fungus Erysiphe polygoni D.C. In recent years during warm, dry summers, the incidence of this disease has increased on Ontario-grown rutabagas (Shattuck and Parry, 1990). Disease symptoms include leaf purpling, thus giving a blotchy appearance (Fig. 1); premature leaf abscission; and plant stunting. In addition, severely infected plants with few leaves are difficult to harvest mechanically. All North American-grown rutabagas are susceptible to powdery mildew infection, and fungicides applied before infection offer the only satisfactory control for this disease (Shattuck et al., 1992). Powdery-mildew-resistant cultivars are needed to reduce or eliminate this dependency on chemicals. PMR-1 rutabaga combines powdery mildew resistance and acceptable plant characteristics and is being released for use in home gardens and for its potential value as a powdery-mildew-resistant source for Cruciferae breeding programs.

\section{Origin}

In 1986, a single, commercially undesirable, self-incompatible plant possessing high resistance to powdery mildew infection was recovered from a rutabaga breeding population (Doucet et al., 1990). This plant was reciprocally crossed via bud pollination to powdery-mildew-susceptible 'Laurentian' rutabaga, which is the commercial standard for Ontario. The resulting seed was bulked, and the $\mathrm{F}_{1}$ generation was selfed. A pedigree program was used to develop several germplasm lines from the $\mathrm{F}_{2}-\mathrm{F}_{4}$ generations. In each generation, plants were selected for field resistance to natural powdery mildew infection and for commercially acceptable characteristics (Shattuck and Proudfoot, 1990). Powdery mildew assessments were made at harvest on

Received for publication 19 Oct. 1993. Accepted for publication 18 Apr. 1994. The cost of publishing this paper was defrayed in part by the payment of page charges. Under postal regulations, this paper therefore must be hereby marked advertisement solely to indicate this fact. the mature leaves and petioles of commercially mature field-grown plants. Selected plants were selfed and advanced in the breed-
Fig. 2. Harvested PMR-1 rutabaga. ing program when the visible fungal mycelium and chlorotic or dead tissues associated with powdery mildew infection covered $<5 \%$ of the total surface area of leaves (James, 1971). PMR-1 represents the bulk of five plants selected in the $F_{4}$ generation of one family.

\section{Description}

Overall, the globular shapes, weight, and color of PMR-1 roots are commercially acceptable (Fig. 2 and Table 1). The flavor of raw or steamed PMR-1 roots is milder and sweeter than that of roots of 'Laurentian'. PMR-1 roots have been successfully cold-stored for 4 months at 1 to $3 \mathrm{C}$ and $>90 \%$ relative humidity, and plants are self-fertile. Commercially mature PMR-1 plants possess high resistance to the unclassified powdery mildew strain(s) occur-

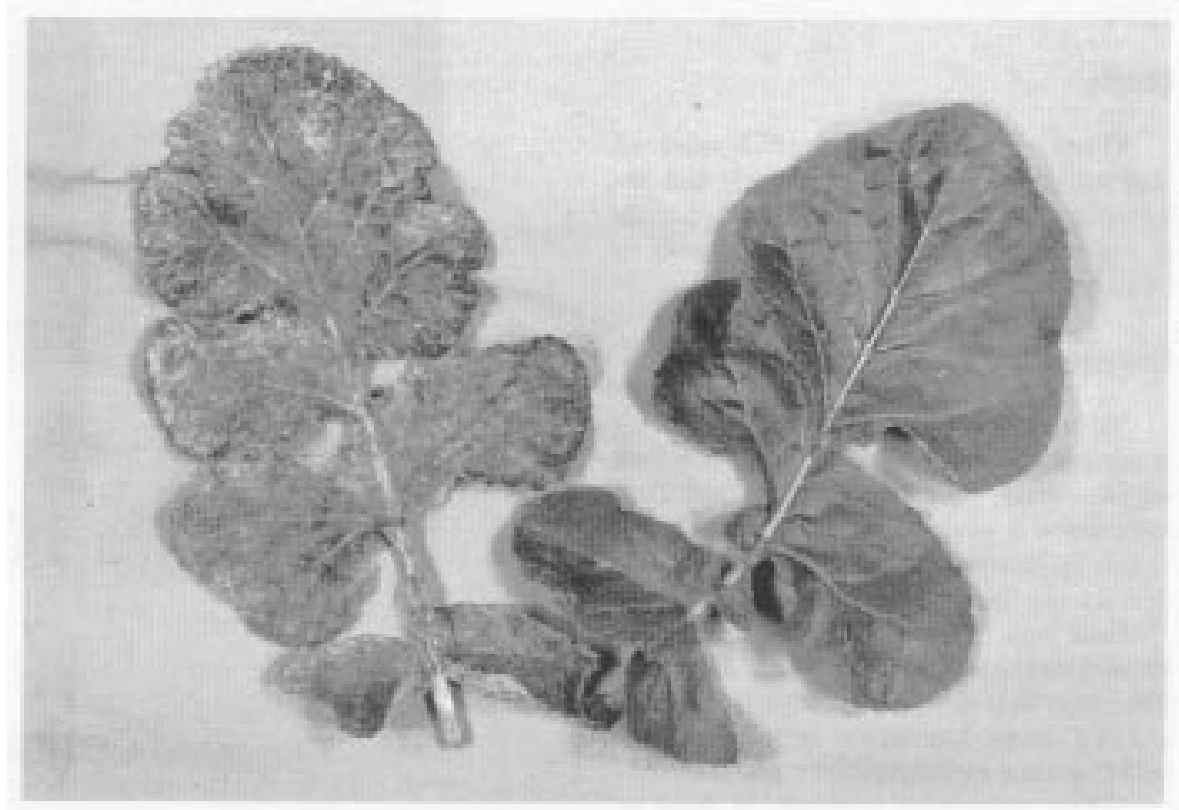

Fig. 1. Powdery-mildew-infected leaves from (left) 'Laurentian' and (right) PMR-1.

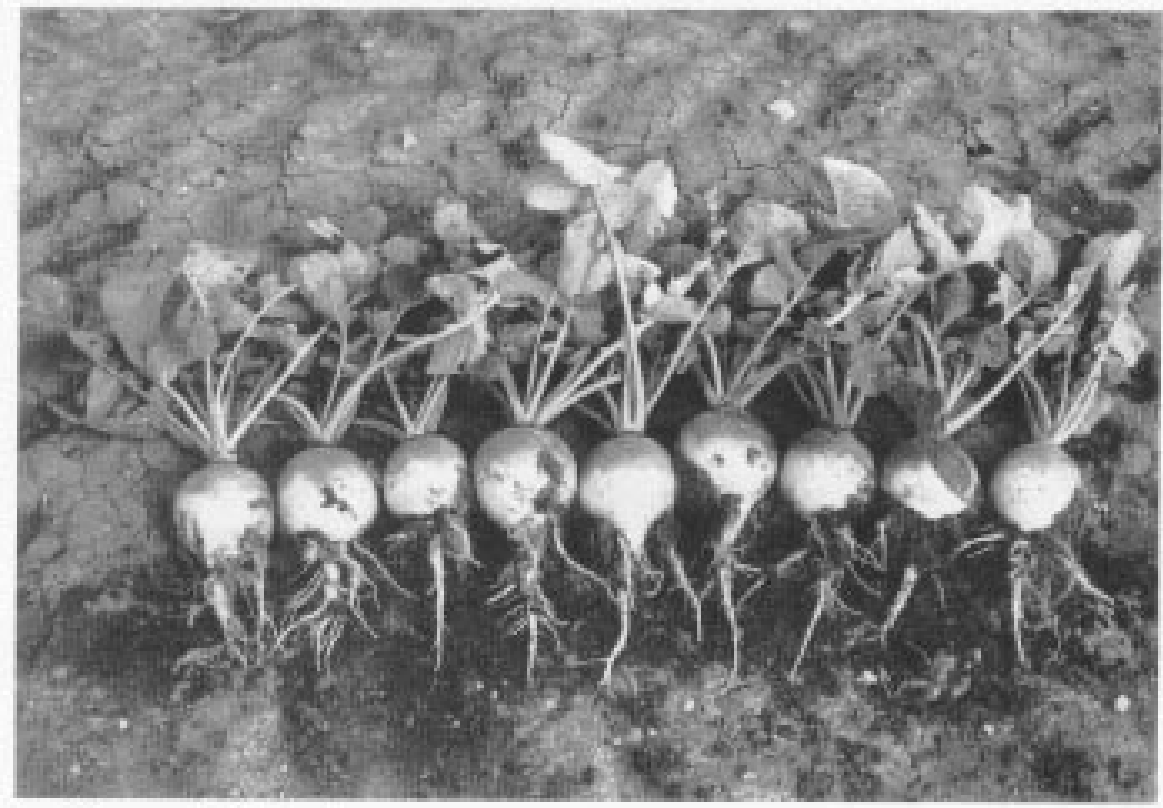


Table 1. Mean root weight and severity of powdery mildew infection on rutabaga genotypes at Centralia, Ont., Canada, during 1993.

\begin{tabular}{lcc}
\hline Genotype & $\begin{array}{c}\text { Root fresh wt } \\
(\mathrm{g} / \mathrm{plant})^{\mathrm{z}}\end{array}$ & $\begin{array}{c}\text { Disease } \\
\text { severity }^{\mathrm{z}, \mathrm{y}} \\
(\%)\end{array}$ \\
\hline PMR-1 & 832 & 2.4 \\
Laurentian & 812 & 39.6 \\
& NS & $*$ \\
\hline
\end{tabular}

${ }^{\mathrm{z}}$ Values based on two replications with nine plants per replication.

${ }^{\mathrm{R}}$ Rating scale represents the mean percentage from 0 to 50 of the upper leaf surface of mature plant leaves covered by visible fungal mycelium and/or disease affected at harvest.

ss, *Nonsignificant or significant at $P \leq 0.05$ by analysis of variance and Wilcoxon $t$ test, respectively. ring at Cambridge and Centralia, Ont., Canada. In 1993, conditions were favorable at Centralia for powdery mildew development, and PMR1 plants showed significantly lower disease severity than 'Laurentian' (Table 1). When challenged by E. polygoni, PMR-1 leaf tissues develop necrotic purple lesions under fungal mycelium. The maturity dates for PMR-1 and 'Laurentian' are similar.

\section{Availability}

Inquiries concerning PMR-1 rutabaga should be directed to Sharpes International Seeds Limited, Sleaford, Lincs NG34 7HA, England.

\section{Literature Cited}

Doucet, R., V.I. Shattuck, and L.W. Stobbs. 1990 Rutabaga germplasm 'TuMV-R' possessing resistance to turnip mosaic virus. HortScience 25:583-584.

James, W.C. 1971. An illustrated series of assessment keys for plant diseases, their preparation and usage. Can. Plant Dis. Surv. 51:39-65.

Shattuck, V.I., B. Brolley, and B. Ripley. 1992. Evaluation of fungicides for control of powdery mildew on rutabaga. Fungicide \& Nematicide Tests 47:127.

Shattuck, V.I. and R. Parry. 1990. The occurrence of powdery mildew on rutabagas in southern Ontario. Can. Plant. Dis. Surv. 70:15-16.

Shattuck, V.I. and K.G. Proudfoot. 1990. Rutabaga breeding. Plant Breeding Rev. 8:217-247. 